\title{
PHARMACOGNOSTICAL AND PHYTOCHEMICAL STANDARDIZATION OF PHYSALIS MINIMA L. LEAF
}

\author{
DIBYENDU SHIL ${ }^{*}$, DAMIKI LAL001, SMRITI REKHA CHANDA DAS ${ }^{1}$, SUVAKANTA DASH$^{2}$
}

${ }^{1}$ Girijananda Chowdhury Institute of Pharmaceutical Science, Azara, Hathkhowapara, Guwahati 781017, India, ${ }^{2}$ Regional Institute of Pharmaceutical Science and Technology, Agartala 799006, India

Email: dibyendu0684@rediffmail.com

Received: 19 Jul 2019, Revised and Accepted: 30 Sep 2019

\section{ABSTRACT}

Objective: To evaluate the pharmacognostical and phytochemical parameters of Physalis minima leaf.

Methods: The leaf of Physalis minima was examined for macroscopical, microscopical, physicochemical parameters and fluorescence analysis. Extracts obtained from the leaf was analyzed for phytochemical screening and estimation of total tannin, phenolic and flavonoid content following the standard procedure available in the literature.

Results: Morphologically, the leaf was found to be ovate in shape, 5 to $8 \mathrm{~cm}$ long and up to $3 \mathrm{~cm}$ width with dentate margin, asymmetrical base, hairy surface, reticulate veins on each side of midrib, green in colour, characteristic odour and slight bitter in taste. Microscopic study has shown the important diagnostic characters of Solanaceae family which is characterized by presence of dorsiventral leaf with anomocytic stomata, grandular or uniseriate trichomes and cluster crystal of calcium oxalate. Physicochemical parameters like foreign organic matter (0.78\%), loss on drying (8.23\%), total ash (11.4\%), acid insoluble ash (2.2\%), water-soluble ash (6.1\%), sulphated ash (2.4\%) alcohol soluble extractive (10.4\%), watersoluble extractive $(9.5 \%)$, ether soluble extractive (1.8\%) foaming index (below 100), swelling index (1), volatile oil and heavy metal content were quantified. Phytochemical analysis of different extracts of Physalis minima leaf has shown the presence of phytoconstituents viz. alkaloids, steroids, tannin, flavonoids, protein. Quantification of phytoconstituents was also reported like phenols ( $10.59 \pm 0.65 \mathrm{mg} / \mathrm{gm}$ equivalent to tannic acid), tannin $(8.24 \pm 0.27 \mathrm{mg} / \mathrm{gm}$ equivalent to tannic acid) and flavonoids (87.17 $\pm 0.87 \mathrm{mg} / \mathrm{gm}$ equivalent to rutin) respectively.

Conclusion: This present study was provided the qualitative and quantitative standard of Physalis minima will help to prevent the possible steps of adulteration with other species of the same genus.

Keywords: Physalis minima, Leaf, Standardization, Pharmacognostical, Physicochemical, Phytochemical

(C) 2019 The Authors. Published by Innovare Academic Sciences Pvt Ltd. This is an open-access article under the CC BY license (http://creativecommons.org/licenses/by/4.0/) DOI: http://dx.doi.org/10.22159/ijpps.2019v11i11.34995

\section{INTRODUCTION}

Medicinal plants have become a promising source of medication in developed as well as a developing country. In recent days due to the increasing of demand of plant-based medicine, pharmaceutical industries are also showing interest on formulation with natural products. It is well known that traditional knowledge is behind the concept of medicinal plants based therapy but the maximum of those medicinal plants are not standardized so far. Standardization includes pharmacognostic studies that assist in the authentication and identification of the plant materials and phytochemical studies helps to explore the phytoconstituents present in the plant responsible for therapeutic activity. Therefore standardization is essential in respect to ensure the quality, purity, effectiveness, and safety of herbal products [1]

Physalis minima belonging to the family Solanaceae (fig. 1) is an annual, small (1-meter height), delicate and erect plant. The plant is distributed in the wastelands and roadsides in India, Bangladesh, Afghanistan, Baluchistan, tropical Africa and Australia [2]. Commonly, the plant is known as wild cape-gooseberry (English) and pokmou (Assamese). The plant has a remarkable effect in folklore medicine as tonic, diuretic and purgative, the leaf juice when mixed with water and mustard oil is used for the treatment of earache, decoction of the root, leaf or fruit was taken as an ingredient along with tea for the treatment of high blood pressure, diabetes and malaria $[3,4]$. Some of these medicinal values were scientifically documented $[5,6]$. Phytochemically, the aerial part of the plant has been reported to bear various classes of plant components such as saponins, tannins, alkaloids, alkenyl phenols, glycoalkaloids, flavonoids, sesquiterpenes lactones, terpenoids [7]. From the extensive literature survey and to the best of authors' knowledge, there was no scientific evidence reported on the quality control standard of the leaf part of Physalis minima. Hence, the objective of the present study was aimed to explore the standard monograph of the leaf of Physalis minima, taking into account the pharmacognostical, physicochemical and phytochemical aspects.

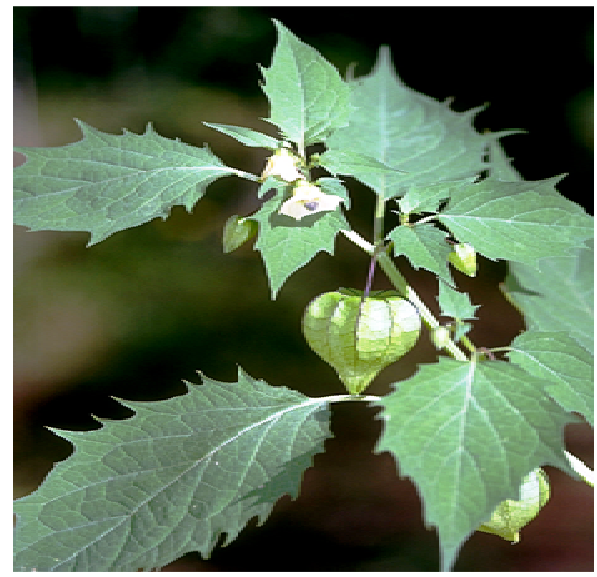

Fig. 1: Physalis minima plant

\section{MATERIALS AND METHODS}

Chemicals

Reagents like phloroglucinol, sodium nitroprusside, pyridine, folin ciocalteu and anisaldehyde were used for study obtained from Alpha 
Chemika, Andheri, Mumbai. All other reagents and solvents used for experiments were analytical grade and purchased from Fisher scientific laboratory, Andhra Pradesh.

\section{Plant material}

Leaf of Physalis minima was collected from Azara, Kamrup district, Assam, India and the plant were authenticated by Dr. P. P. Baruah (HOD, Department of Botany, Gauhati University, India). The voucher specimen no. of Physalis minima leaf (Acc no. 18175) was kept at the Department of Pharmacognosy, Girijananda Chowdhury Institute of Pharmaceutical Sciences, Assam for future reference. The collected plant materials were then subjected to wash with running water, followed by shade drying for $15 \mathrm{~d}$. The dried leaves were pulverized by using the mechanical grinder and passed through 40mesh sieve to get coarse powder and stored in airtight containers for experimental study.

\section{Macroscopic, microscopic and powder drug evaluation}

The morphological characters like shape, size, taste, colour, odour of leaf was established and documented accordingly [8]. Microscopic evaluation was done by using a microtome technique. The fresh sections were immersed in chloral hydrate solution to make chlorophyll free. These sections were further dehydrated with absolute alcohol followed by stained with the mixture of phloroglucinol and conc. $\mathrm{HCl}$ (1:1) and finally placed on glass slide for histological study under binocular microscope with different magnification [9]. For the study of isolated tissue, the dried powdered plant material was treated with a mixture of concentrated nitric acid and potassium chlorate, washed with distilled water and finally mounted in different detecting reagents such as Phloroglucinol and conc. $\mathrm{HCl}$ (1:1), iodine solution for observation [10]. The photographs were taken at different magnifications (10x and $40 \times$ ) with the help of binocular digital microscope.

\section{Determination of physicochemical parameter}

Powdered leaf of Physalis minima was examined for the estimation of physicochemical parameters viz. ash value, loss on drying, foreign matter, extractive matter, foaming index, swelling index, volatile oil and heavy metal content based on the standard method described in WHO guideline [11].

\section{Fluorescence analysis of powdered drug}

The crude powdered drug was reacted with different chemical reagents consist of acidic and basic medium and fluorescence characteristics were examined under UV light (254 nm and $366 \mathrm{~nm}$ ) as well as daylight $[12,13]$.

\section{Quantification of crude fibres}

Quantitative determination of crude fiber content was done by boiling the powdered crude drug with nitric acid (10\%), filtered and washed the residue with boiling water and further treated with $\mathrm{NaOH}(2.5 \%)$, filtered and weighed the crude fibres. The percentage (w/w) of crude fibers content was calculated [13].

\section{Preparation of extract}

About $250 \mathrm{gm}$ of the powdered crude drug was extracted by hot percolation process with petroleum ether followed by cold maceration process with benzene, diethyl ether, chloroform, acetone, ethyl acetate and methanol accordingly for about $72 \mathrm{~h}$. The extracts were then filtered with whatman filter paper and concentrated under vacuum by using rotary evaporator (Buchi India Pvt Ltd.) and stored in a desiccator until further use [14, 15].

\section{Preliminary phytochemical screening}

All the extracts were undergone preliminary phytochemical analysis to identify the nature of secondary metabolites such as alkaloids, carbohydrate, glycosides, saponins, steroids, terpenoids, phenolics, flavonoids and protein present in the plant [16].

\section{Quantitative estimation of polyphenolic components}

A range of phytochemicals was estimated quantitatively based on the observation of preliminary phytochemical analysis. Therefore, estimation of total flavonoid content (where rutin used as standard) [17], total phenolics and tannin content (whereas tannic acid was used as reference standards) [18] were determined incorporates with UV spectrophotometer. Results are calculated and expressed as the mean \pm S. E. M using a statistical linear regression method.

\section{RESULTS}

\section{Morphological evaluation}

The macroscopic evaluation of Physalis minima leaf is described in table 1.

Table 1: Morphological evaluation of Physalis minima leaf

\begin{tabular}{lll}
\hline S. No. & Features & Descriptions \\
\hline 1 & Shape & $\begin{array}{l}\text { Leaves are ovate in shape, the margin is dentate, apex is acute, 4-6 veins are reticulate present on each side of midrib } \\
\text { and lateral veins on lamina are run towards marginal teeth. } \\
\end{array}$ \\
2 & Size & Leaves are 5 to $8 \mathrm{~cm}$ long and up to a maximum $3 \mathrm{~cm}$ width. \\
3 & Colour & Green. \\
4 & Odour & Characteristic. \\
5 & Taste & Slight bitter. \\
6 & Extra features & Base asymmetrical, petiole long, texture thin, surface minutely hairy, midrib prominent on lower surface. \\
\hline
\end{tabular}

\section{Microscopical evaluation}

Transverse section of the Physalis minima leaf has represented in fig. 2A. Midrib of leaf composed of upper (U. Ep) and lower (L. Ep) epidermis, followed by 3-4 layers of collenchymatous cells (Col) present below the upper epidermis. Cortical parenchyma present throughout the midrib region, which surrounds the vascular bundle area and spread up to above lower epidermis. Vascular bundles were seen where xylem vessels (Xy) covered by phloem cells (Ph). Xylems were clearly stained violet in phloroglucinol and $\mathrm{HCl}$. Pericyclic fibers (Pcf) were seen outside of vascular bundle covering the xylem and phloem.

Lamina (fig. 2B) characterized by the dorsiventral arrangement of cells composed of upper epidermis, mesophyll, and lower epidermis. Upper epidermis is single layer rectangular parenchymatous cells contain multicellular glandular trichomes (GTr), anomocytic stomata (St) (fig. 2C) surrounded by varying number of subsidiary cell (SC1, SC2, SC3 or somewhere SC4). Mesophyll composed of palisade parenchyma (PL) just below upper epidermis and spongy parenchymatous cells (SP) above lower epidermis (PL and SP are arranged dorsoventrally) and in the junction of these two (PL and SP) spiral-shaped xylem (Xy) vessels were seen. Palisade parenchyma is compact, radially elongated cell and occupies the 3/5 of lamina. The similar lower epidermis also consists of single-layer rectangular parenchymatous cells contain multicellular glandular trichomes (GTr), anomocytic stomata (St) (fig. 2D) surrounded by varying number of subsidiary cell (SC1, SC2, SC3 or somewhere SC4). The above cells have observed with different magnification (10x and $40 \times$ ) under the compound microscope. 

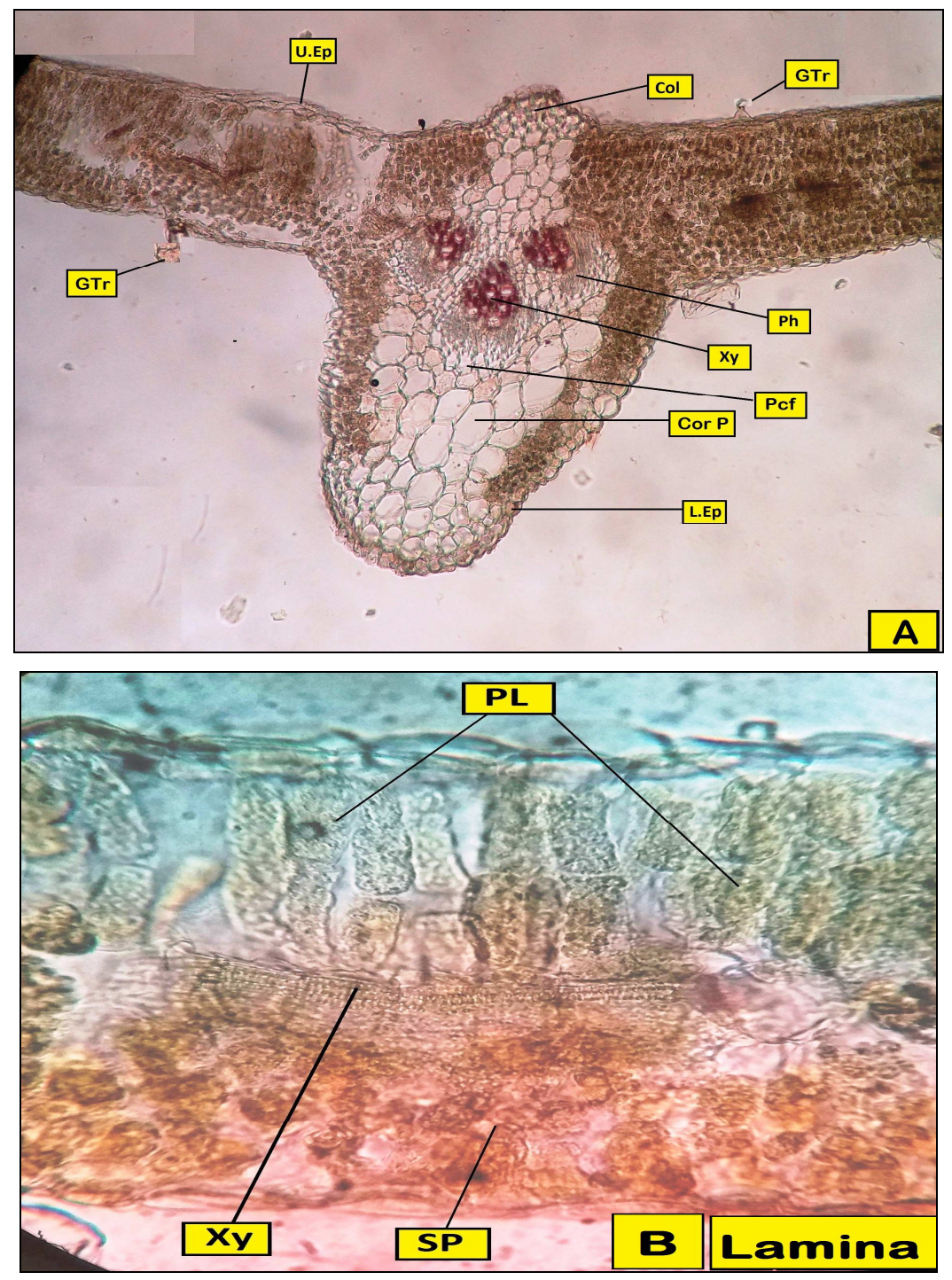

Fig. 2: Transverse section (40× magnification) of the leaf of Physalis mnima through Midrib (A), and Lamina (B), [Abbreviations-U. Ep: Upper Epidermis; L. Ep: Lower epidermis; Col: Collenchyma; Ph: Phloem; Xy: Xylem; Cor P: Cortical Parenchyma; GTr: Glandular trichome; Pcf: Pericyclic fiber; PL: Palisade parenchyma; SP: Spongy Parenchyma]

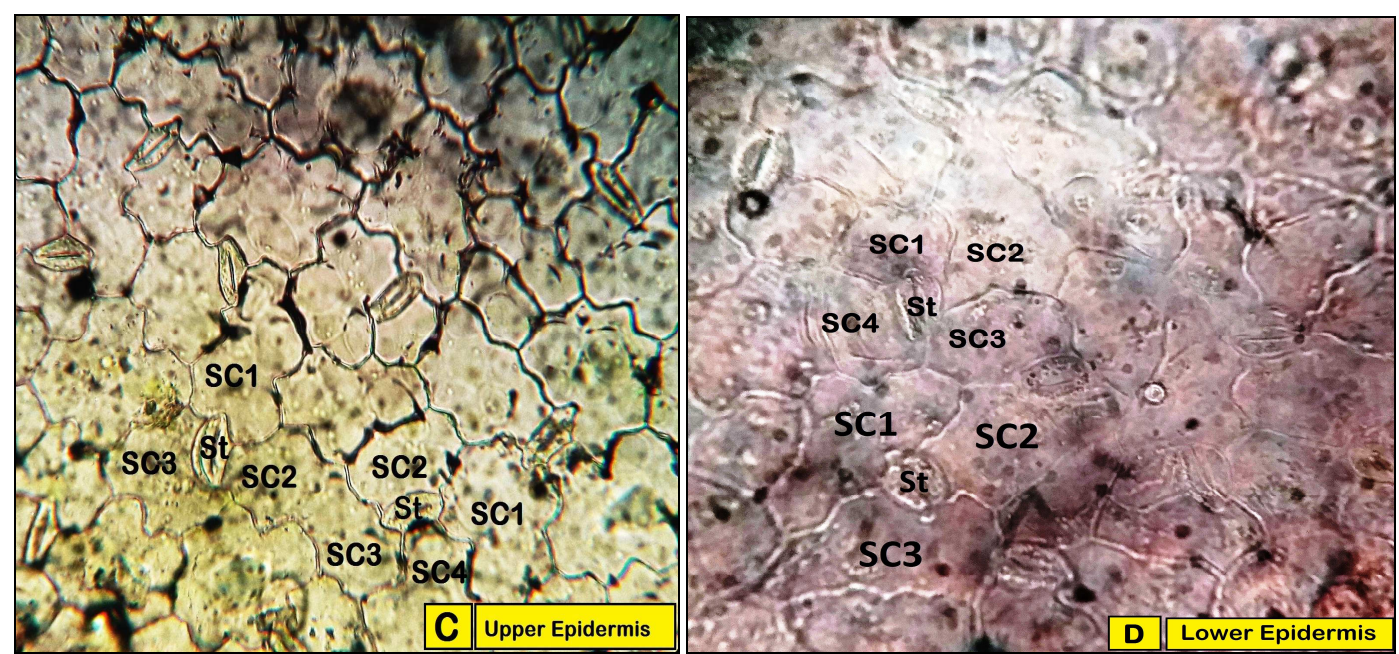

Fig. 2: Transverse section (10 $\times$ and $40 \times$ magnification) of the stomata of the leaf of Physalis minima through Upper epidermis (C), and Lower epidermis (D)

[Abbreviations-St: Stomata; SC: Subsidiary cells] 


\section{Microscopical evaluation of powder drug}

The powdered drug was mounted in the mixture of phloroglucinol with HCL (1:1) for the detection of lignification and also with diluted iodine solution for examining the presence of starch grains. Various isolated cells like fibre $(\mathrm{Fb})$, rosette crystal of calcium oxalate (Ca. Ox), uniseriate multicellular trichomes (UTr), spiral-shaped xylem vessel $(\mathrm{XyV})$, xylem $(\mathrm{Xy})$, anomocytic stomata (St), parenchymatous cells (PC) were observed with different magnification $(10 \times$ and $40 \times)$ (fig. 3) under the compound microscope. Starch grains were not found.

\section{Physicochemical characteristics}

Results of the physicochemical parameters of the powdered leaf of Physalis minima are shown in table 2.
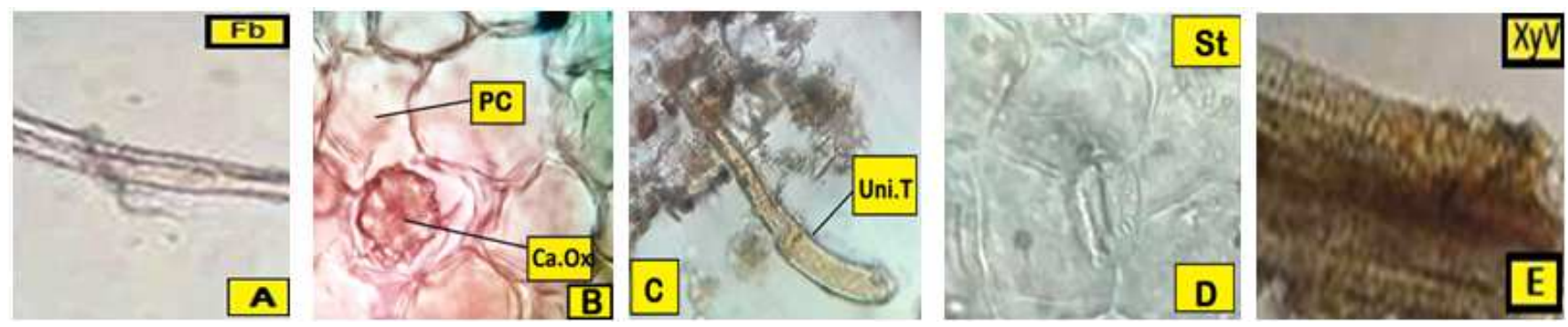

Fig. 3: Powder study of the leaf of Physalis minima [10x and 40x magnification], [Abbreviations-Fb: Fibre (A); Ca. Ox: Calcium oxalate crystal (B); PC: Parenchymatous cell (B), Uni. T: Uniseriate Trichome (C); St: Stomata (D); XyV: Xylem Vessels (E)]

Table 2: Physicochemical parameters of the powdered leaf of Physalis minima

\begin{tabular}{lll}
\hline S. No. & Physicochemical parameters & Result \\
\hline 1 & Ash value & \\
& Total ash & $11.4 \% \mathrm{w} / \mathrm{w}$ \\
& Acid insoluble ash & $2.2 \% \mathrm{w} / \mathrm{w}$ \\
& Water-soluble ash & $6.1 \% \mathrm{w} / \mathrm{w}$ \\
& Sulphated ash & $2.4 \% \mathrm{w} / \mathrm{w}$ \\
2 & Loss on drying & $8.23 \% \mathrm{w} / \mathrm{w}$ \\
3 & Foreign matter & $0.78 \% \mathrm{w} / \mathrm{w}$ \\
4 & Extractive value & \\
& Alcohol soluble extractive & $10.4 \% \mathrm{w} / \mathrm{w}$ \\
& Water-soluble extractive & $9.5 \% \mathrm{w} / \mathrm{w}$ \\
& Ether soluble extractive & $1.8 \% \mathrm{w} / \mathrm{w}$ \\
5 & Swelling factor & 1 \\
6 & Foaming index & Below 100 \\
7 & Volatile oil content & Absent \\
8 & Heavy metals & \\
& Lead (Pb) & Not more than $1 \mathrm{ppm}$ \\
& Cadmium (Cd) & Not more than $1 \mathrm{ppm}$ \\
& Zinc (Zn) & Not more than $1 \mathrm{ppm}$ \\
& Mercury (Hg) & Not more than $1 \mathrm{ppm}$ \\
\hline
\end{tabular}

Table 3: Fluorescence analysis of powder drug of the leaf of Physalis minima

\begin{tabular}{llll}
\hline Powder+reagent & Fluorescence in daylight & Fluorescence in (254 nm) & Fluorescence in (365 nm) \\
\hline Powder drug & $\mathrm{NF}$ & $\mathrm{NF}$ & NF \\
Powder+Methanol & $\mathrm{NF}$ & Brown & Dark brown \\
Powder+1 $\mathrm{N} \mathrm{NaOH}$ in methanol & Light brown & Dark green & Bluish-green \\
Powder+1 $\mathrm{N} \mathrm{HCl} \mathrm{in} \mathrm{methanol}$ & $\mathrm{NF}$ & Reddish-brown & Dark violet \\
Powder+1 $\mathrm{HNO}_{3}$ in methanol & $\mathrm{NF}$ & Reddish-brown & Dark blue \\
Powder+Picric acid (5\%) & Yellow & Pale yellow & Yellowish green \\
Powder+FeCl $(5 \%)$ & Light brown & Orange & Dark brown \\
Powder+KOH $(5 \%)$ & $\mathrm{NF}$ & Pale yellow & Dark green \\
\hline
\end{tabular}

NF: No fluorescence

\section{Fluorescence powder drug analysis}

Results of the fluorescence characteristics of the powdered leaf of Physalis minima with different reagents are represented in table 3.

\section{Quantification of the crude fiber content}

Crude fibre content was found to be $0.35 \% \mathrm{w} / \mathrm{w}$ per gram of the plant material.

\section{Quantification of the extractive value of different extracts}

The extractive values of the individual solvent extracts are shown in table 4. It was observed that methanol extract produced the maximum percentage of yield compared to other solvents.

\section{Preliminary phytochemical screening}

The results from the preliminary phytochemical screening of different extract of Physalis minima leaf are represented in table 5. 
Table 4: Percentage of yield of leaf of Physalis minima extract from different solvents

\begin{tabular}{lll}
\hline S. No. & Solvent used & Percentage of yield \\
\hline 1 & Petroleum Ether & $1.8 \% \mathrm{w} / \mathrm{w}$ \\
2 & Benzene & $0.87 \% \mathrm{w} / \mathrm{w}$ \\
3 & Diethyl ether & $1.5 \% \mathrm{w} / \mathrm{w}$ \\
4 & Chloroform & $4.2 \% \mathrm{w} / \mathrm{w}$ \\
5 & Acetone & $4.4 \% \mathrm{w} / \mathrm{w}$ \\
6 & Ethyl acetate & $5.3 \% \mathrm{w} / \mathrm{w}$ \\
7 & Methanol & $10.4 \% \mathrm{w} / \mathrm{w}$ \\
\hline
\end{tabular}

Table 5: Phytochemical screening of various extracts of leaf of Physalis minima

\begin{tabular}{|c|c|c|c|c|c|c|c|}
\hline $\begin{array}{l}\text { Bioactive } \\
\text { constituents }\end{array}$ & $\begin{array}{l}\text { Pet. } \\
\text { ether }\end{array}$ & Benzene & $\begin{array}{l}\text { Diethyl } \\
\text { ether }\end{array}$ & Chloroform & Acetone & $\begin{array}{l}\text { Eth. } \\
\text { acetate }\end{array}$ & Methanol \\
\hline Alkaloids & - & _ & _- & + & - & - & + \\
\hline Flavonoids & - & - & - & + & - & $\bar{t}$ & + \\
\hline Saponins & - & - & - & _- & - & - & _- \\
\hline Carbohydrates & - & - & - & - & - & - & - \\
\hline Steroids & - & - & - & + & - & - & + \\
\hline Tannins & - & - & - & _- & + & - & + \\
\hline Terpenoids & - & - & - & - & _ & - & _- \\
\hline Proteins & & & - & + & - & + & + \\
\hline
\end{tabular}

Indications: [+] denotes present; [-] denotes absent

\section{Quantitative estimation of polyphenolic components}

Total phenols, tannin and flavonoid content in methanolic extract of Physalis minima leaf were found to be $10.59 \pm 0.65 \mathrm{mg} / \mathrm{gm}$ equivalent to tannic acid, $8.24 \pm 0.27 \mathrm{mg} / \mathrm{gm}$ equivalent to tannic acid (TAE) and $87.17 \pm 0.87 \mathrm{mg} / \mathrm{gm}$ equivalent to rutin (RE) respectively.

\section{DISCUSSION}

Since thousands of years, natural products play a promising role as source of therapeutic agents in the management of health care system and prevention of diseases. According to World Health Organization (WHO), about $80 \%$ of the world's populations have faith on efficacy of traditional medicine [19]. Among these traditional drugs few were officially standardized and documented properly but it is essential to establish the standard monograph of all unexploited traditional medicine to minimize mishandling, chances of adulteration/substitution. Therefore the aim of the study was proposed to develop a standard monograph profile of the leaf of Physalis minima by pharmacognostic, physicochemical, phytochemical standardize methods. No such literature has been found in this aspect. Pharmacognostical parameters such as morphological and microscopical evaluations were considered to be leading steps of standardization process. Macroscopical studies of leaf of Physalis minima revealed that the dentate margin, presence of 4-6 veins on each side of midrib, lateral veins are run towards marginal teeth, reticulate veins, base asymmetrical and long petioles. Microscopically studies have shown the important diagnostic characters of Solanaceae family which is characterized by presence of dorsiventral leaf, anomocytic stomata, grandular or uniseriate trichomes and cluster crystal of calcium oxalate [20].

The physicochemical parameters were evaluated to determine the presence of adulteration as well as to measure the purity of crude drugs in powder form. Ash value was performed to quantify the inorganic matters in the drug sample [21]. Total ash has confirmed the presence of salt of carbonate, phosphate and silicates of sodium, calcium and magnesium, whereas acid insoluble ash detects the existence of silica, water-soluble ash confirmed the amount of inorganic substances exhausted by water and sulphated ash represented the amount of salt in powder drug. As per WHO, crude drug is considered to be more safe to use as it contain inorganic matters within the said limit. So, present study has revealed that the inorganic matters found to be less in quantity in the powder leaf of Physalis minima. Moisture content was found to be lower limit which proved the less chance of microbial contamination in powdered drug. Extractive values were determined to know the solubility factor of crude drug including nature of bio constituents present in it [22]. The result of extractive values confirmed that most of the bio- constituents were soluble in alcohol. The swelling factor signifies the existence of mucilages, gums, pectin, hemicelluloses in the plant material [9]. In this study the swelling factor was found to be less than $1 \mathrm{ml}$, which indicates the low quantity of above-mentioned parameters in the plant sample. The foaming index was carried out to estimate saponins content in crude drugs [23] which found to be low quantity in experimental study. Crude drugs may contaminate with heavy metal though it is not safe to consume without its estimation. In experimental analysis heavy metals were found to be within the limit prescribed by WHO [13]. Fluorescence analysis of powdered drugs has revealed the nature of bioactive constituents which shown fluorescence under various wavelengths of UV rays [24]. Preliminary phytochemical analysis of different extracts has shown the presence of bioactive compound viz. alkaloids, steroids, tannin, flavonoids, and protein; however, majority of compounds were present in methanolic extract of leaf of Physalis minima.

\section{CONCLUSION}

In conclusion, the present investigation on pharmacognostic and physicochemical standardization of leaf serves as a significant aid for maintaining the purity and authenticity of Physalis minima. Hopefully, these standard parameters will help to prevent the possible steps of adulteration with other species of the same genus. In addition, preliminary phytochemical screening of different extracts facilitates the presence of secondary metabolites in the plant which will direct the right pathway for the isolation of bioactive compounds in future work.

\section{ACKNOWLEDGEMENT}

The authors thanks to the Shrimanta Shankar Academy society for providing facilities to do the experimental work at Girijananda Chowdhury Institute of Pharmaceutical Science, Azara, Guwahati and also thankful to Dr. P. P. Baruah, HOD, Department of Botany, Gauhati University, India for authentication of plant.

\section{AUTHORS CONTRIBUTIONS}

All the authors have contributed equally

\section{CONFLICT OF INTERESTS}

All authors have none to declare

\section{REFERENCES}

1. Prasad SK, Sahu AN, Hemalatha S. Cytomorphological and physicochemical evaluation Cryptocoryne spiralis (Retzius) wydler. J Herbs Spices Med Plants 2012;18:304-7. 
2. Supriya SK, Rohit AG, Rajashekhar N. Identity of Tankari (Physalis Minima Linn.) in ayurvedic classics: a literature review. Anc Sci Life 2016;36 Suppl 1:6-11.

3. Fasihuddin BA, Ghazally I. Medicinal plants used by kadazandusun communities around crocker range. ASEAN Rev Biodiversity Environ Conservation 2003;7:1-10.

4. Karpagasundari C, Kulothungan S. Free radical scavenging activity of Physalis minima linn leaf extract (PMLE). J Med Plant Stud 2014;2 Suppl 4:59-64.

5. Jyothibasu T, Venkata Ramana K, Sreenu T, Ch Narasimha Raju Bh. Diuretic activity of methanolic extract of Physalis minima leaves. Scholars Research Library. Der Pharm Lett 2012;4 Suppl 6:1832-4.

6. Patel T, Shah K, Jiwan K, Shrivastava N. Study on the antibacterial potential of Physalis Minima linn. Indian J Pharm Sci 2011;73 Suppl 1:111-5.

7. Karpagasundari C, Kulothunga S. Analysis of bioactive compounds in Physalis minima leaves using GC MS, HPLC, UVVIS and FTIR techniques. J Pharmacogn Phytochem 2014;3 Suppl 4:196-201.

8. Khandelwal KR. Practical pharmacognosy, techniques and experiment. $22^{\text {nd }}$ ed. Pune: Nirali Prakashan; 2012.

9. Khare P, Kishore K, Sharma DK. A study on the standardization parameters of Bauhinia variegate. Asian J Pharm Clin Res 2017;10:133-6.

10. Johansen DA. Plant micro-technique. New York: McGraw Hill; 1940.

11. Quality control methods for herbal materials. World health Organization. Geneva: Switzerland; 2011.

12. Chase CR, Pratt R. Fluorescence of powdered vegetable drugs with particular reference to the development of a system of identification. J Am Pharm Assoc 1949;38 Suppl 6:324-31.

13. Dibyendu S, Suvakanta D, Damiki L. A comprehensive quality control standardization of Mirabilis jalapa L. tuberous root. Int J Res Pharm Sci 2017;8 Suppl 3:336-41.
14. Khare P, Kishore K, Sharma DK. A study on the standardization parameters of Bauhinia variegate. Asian J Pharm Clin Res 2017; 10:133-6.

15. Harborne JB. The flavonoids: advances in research. Chapman and Hall. London J Sci Food Agric 1973;3:90-103.

16. Rawat $\mathrm{P}$, Bachheti RK, Kumar N, Rai N. Phytochemical analysis and evaluation of in vitro immunomodulatory activity of Rhododendron arboreum leaves. Asian J Pharm Clin Res 2018;11:123-8.

17. Kumaran A, Karunakaran J. In vitro antioxidant activities of methanol extracts of five Phyllanthus species from India. Food Sci Technol 2007;40 Suppl 2:344-52.

18. Makkar HPS. Quantification of tannins in tree foliage: A laboratory manual for the FAO/IAEA coordinated research project on the use of nuclear and related techniques to develop simple tannin assays for predicting and improving the safety and efficiency of feeding ruminants of tanniniferous tree foliage, working document. Vienna: FAO/IAEA; 2000.

19. Traditional medicine strategy. World Health Organisation. Geneva: Switzerland; 2002-2005.

20. Metcalfe CR, Chalk L. Anatomy of dicotyledons. Vol II. Oxford, England: Clarendon Press; 1950.

21. Ahuja J, Suresh J, Deep A, Madhuri, Pratyusha, Ravi. Phytochemical screening of Aerial part of Artemisia parviflora Roxb: a medicinal plant. Der Pharm Lett 2011;3:116-24.

22. Sonia NS, Jessykutty PC. Drying technologies for good quality crude drug production of medicinal plants-a review. Int J Med Pharm Sci 2016;6:59-72.

23. Kala C, Ali SS, Chaudhary S. Comparative pharmacognostical evaluation of Costus speciosus (Wild Ginger) and Zingiber officinale (Ginger) rhizome. Int J Curr Pharm Res 2016;8:19-23.

24. Ruwali P, Ambwani TK, Gautam P, Thapliyal A. Qualitative and quantitative phytochemical analysis of Artemisia indica willd. J Chem Pharm Res 2015;7:942-9. 